\title{
The Relationship of Exclusive Breast Milk With Stunting in Children Under the Age of Two Years Tapung Kampar Distric
}

\author{
Yulia Febrianita ${ }^{1}$, Ainil Fitri ${ }^{2}$, Andalia Roza ${ }^{3}$, Roni Saputra ${ }^{4}$ \\ D III Nursing Program Universitas Abdurrab Pekanbaru, Indonesia
}

\begin{abstract}
Based on the 2013 Basic Health Research (RISKESDAS), Short Toddler is one of the health problems of toddlers in Indonesia. The purpose of this study was to identify the relationship between exclusive breastfeeding and the incidence of stunting in children under two years of age in Tapung, Kampar Regency. The study uses observational analysis research methods with case control. The sample in this study were mothers with children under the age of two years in Tapung, Kampar district. The research instrument used was a questionnaire and a weight and height measurement tool. Bivariate data used chi square test with $p$ value: 0.05 . The results in this study were toddlers who were not exclusively breastfeeding who experienced more stunting, namely 52 respondents. Statistical test results obtained $P$ Value $<\alpha=0.05$ which is $\mathbf{0 , 0 0 0}$. The conclusion of the study is the relationship between exclusive breastfeeding and stunting in the Kampung Tapung District with a $P$ value of 0,000 .
\end{abstract}

Keywords:- Exclusive Breast Milk, Stunting.

\section{INTRODUCTION}

Stunting is defined as a chronic malnutrition problem caused by feeding that is not in accordance with nutritional needs so that nutrient intake is lacking in a long time (Millennium Challenga Account Indonesia, 2014). Based on the 2013 Basic Health Research (RISKESDAS), Short Toddler is one of the health problems of toddlers in Indonesia. According to WHO, short toddlers will become a public health problem if the prevalence is more than $20 \%$, in Indonesia, the prevalence of short toddlers in 2013 was $37.2 \%$ so this problem must be addressed. Based on the 2013 Basic Health Research (RISKESDAS), the prevalence of short toddlers also increased compared to neighboring countries such as Malaysia (17\%), Myanmar (35\%), Vietnam (23\%), and Thailand (16\%).

Stunting is influenced by several factors, including factors before birth such as maternal nutrition during pregnancy and factors after birth such as exclusive breastfeeding, nutritional intake of children during growth, infectious diseases, socio-economic, health services, and various other factors that collaborate at the level and a certain degree so that it ultimately leads to failure of linear growth (Fikrina, 2017). Although exclusive breastfeeding is strongly associated with reduced risk of Stunting, it has not been able to completely change people's perceptions regarding the importance of exclusive breastfeeding during the first 6 months of life (Victoria $\mathrm{C}$ et al, in Paramashanti et al, 2015). This is indicated by the low percentage of babies who are breastfed in Indonesia. In 2016 the percentage of babies getting ASI based on age group was $54 \%$ while in 2017 , babies got Exclusive ASI according to their age of $46.7 \%$.

\section{LITERATUR REVIEW}

\section{A. Exclusive Breast Milk}

Breast milk has many benefits for babies. Breast milk can reduce the risk of lack of various nutrients because breast milk can reduce the risk of lack of various nutrients because milk contains protein, fat, vitamins, minerals, water and enzymes needed by infants (Mufidah et al., 2015). Research that proves that exclusive breastfeeding in developing countries has succeeded in saving about 1.5 million babies per year is one of the basic recommendations for exclusive breastfeeding until six months old by WHO, UNICEF, and the Minister of Health of the Republic of Indonesia (Mamonto, 2015).

\section{B. Stunting}

Short toddler (Stunting) is a chronic malnutrition problem caused by a lack of nutritional intake in a long time due to food that is not in accordance with nutritional needs (Amaliah N, K and B.Ch.Rosha, 2012). Human growth is the result of interactions between genetic factors, hormones, nutrients, and energy with environmental factors (Oktarina, Z and T. Sudiarti, 2013). Stunting is a chronic condition that describes stunted growth due to long-term malnutrition. Stunting according to WHO Child Growth Standard is based on body length index by age (PB / U) or height by age (TB / U) with a limit (z-score) <-2 SD (Ministry of PDTT, 2017).

Stunting in infants is a consequence of several factors that are often associated with poverty including nutrition, health, sanitation and the environment (Ministry of PDTT, 2017). The main factors causing stunting are: Food intake, infectious diseases and Health and Environmental Health Services. Stunting is a chronic malnutrition that occurs in the womb and during the first two years of a child's life can result in low intelligence and decreased physical capacity which ultimately leads to decreased productivity, slowing economic growth, and prolongation of poverty (Amaliah, N., K. Sari., And B.Ch. Rosha. 2012). 
Research by Febriani et al. (2018) stated that there was a significant relationship between exclusive breastfeeding and the incidence of stunting in infants aged 6-23 months in Lampung Province, where infants who did not receive exclusive breastfeeding were at risk of being stunted 2,808 times compared to infants who received exclusive breastfeeding.

\section{RESEARCH METHODS}

This research uses observational analytic method with a case control research design. The place of research is in Tapung, Kampar Regency. The population in this study are mothers who have toddlers aged 6- 24 months in Tapung, Kampar District. The sample in this study were all mothers who had toddlers aged 6-24 months in Tapung, Kampar District., totaling 132 people with inclusion criteria for toddlers with normal gestational age and weight. The independent variable in this study is the history of exclusive breastfeeding. While the dependent variable is a stunting event. The research instrument used was Microtoise (a tool to measure height) and a questionnaire. Data analysis was performed using the chi square statistic test.

\section{RESEARCH RESULTS AND DISCUSSION}

The results of research conducted in 2020 with 132 respondents using a questionnaire in Kampung Tapar, Riau Province, can be seen in the table below:

\section{A. Univariate Analysis}

\begin{tabular}{|c|c|c|c|}
\hline No & Education & Frequency & $\begin{array}{c}\text { Percentage } \\
(\mathbf{\%})\end{array}$ \\
\hline 1 & $\begin{array}{c}\text { Elementary } \\
\text { school }\end{array}$ & 6 & $5 \%$ \\
\hline 2 & Middle School & 24 & $17 \%$ \\
\hline 3 & High school & 60 & $46 \%$ \\
\hline 4 & Diploma & 20 & $15 \%$ \\
\hline 5 & Bachelor & 22 & $17 \%$ \\
\hline & Total & $\mathbf{1 3 2}$ & $\mathbf{1 0 0}$ \\
\hline
\end{tabular}

Table 1:- Characteristics of Respondents Based on Education

Based on table 1 above of 132 respondents in Tapung, Kampar District, the highest distribution of respondents based on education was high school with 60 respondents $(46 \%)$.

\begin{tabular}{|c|c|c|c|}
\hline No & Profession & Frequency & $\begin{array}{c}\text { Percentage } \\
(\mathbf{\%})\end{array}$ \\
\hline 1 & Teacher & 18 & $14 \%$ \\
\hline 2 & Housewife & 78 & $60 \%$ \\
\hline 3 & Trader & 20 & $14 \%$ \\
\hline 4 & Employee & 12 & $9 \%$ \\
\hline 5 & Entrepreneur & 4 & $3 \%$ \\
\hline \multicolumn{2}{|c|}{ Total } & $\mathbf{1 3 2}$ & $\mathbf{1 0 0}$ \\
\hline
\end{tabular}

Table 2:- Characteristics of Respondents Based on Profession
Based on table 2 above of 132 respondents in Tapung, Kampar district, the distribution of respondents based on the most work was housewives with 78 respondents $(60 \%)$.

\begin{tabular}{|c|c|c|c|}
\hline No & $\begin{array}{c}\text { Monthly } \\
\text { Earnings }\end{array}$ & Frequency & $\begin{array}{c}\text { Percentage } \\
(\boldsymbol{\%})\end{array}$ \\
\hline 1 & $<\mathrm{Rp} .3 .000 .000$ & 90 & $67,5 \%$ \\
\hline 2 & $>$ Rp. 3.000 .000 & 42 & $32,5 \%$ \\
\hline \multicolumn{2}{|c|}{ Total } & $\mathbf{1 3 2}$ & $\mathbf{1 0 0}$ \\
\hline
\end{tabular}

Table 3:- Characteristics of Respondents Based on Monthly Earnings

Based on table 3 above of 132 respondents in Tapung, Kampar Regency, the distribution ofespondents based on the highest monthly income is <Rp. 3,000,000 with 90 respondents $67.5 \%$ ).

\section{B. Bivariate Analysis}

\begin{tabular}{|c|c|c|c|c|}
\hline \multirow{2}{*}{ VARIABLE } & \multicolumn{2}{|c|}{ STUNTING } & TOTAL & $\begin{array}{c}\text { P } \\
\text { Value }\end{array}$ \\
\cline { 2 - 3 } & YES & NO & & 0,000 \\
\hline $\begin{array}{c}\text { Exclusive } \\
\text { Breastfeeding }\end{array}$ & 14 & 45 & 59 & \\
\hline $\begin{array}{c}\text { No Exclusive } \\
\text { Breastfeeding }\end{array}$ & 52 & 21 & 73 & \\
\hline TOTAL & $\mathbf{6 6}$ & $\mathbf{6 6}$ & $\mathbf{1 3 2}$ & \\
\hline
\end{tabular}

Table 4:- Relationship of Exclusive Breastfeeding with Stunting Event

Based on table 4 above of 132 respondents in Tapung, Kampar Regency. The results obtained for toddlers who are not exclusive Asi are more stunted, namely 52 respondents. Statistical test results obtained P Value $<\alpha=0.05$ which is 0,000 .

Growth and development in infancy requires balanced and relatively large amounts of nutrients. However, a baby's ability to eat is limited by the condition of the digestive tract which is still in the maturing stage. The only food that suits the condition of the baby's digestive tract and meets the needs during the first months is breast milk. Children who do not get exclusive breast milk are at higher risk for nutrient deficiencies needed for the growth process. Growth disturbance will result in stunting in children (Soetjiningsih, 2015).

\section{CONCLUSION}

The results of a study conducted in 2020 in Tapung, Kampar Regency, Riau Province, about the Relationship of Exclusive Asi Giving to Stunting Events in Baduta in Tapung, Kampar District, are the relationship between exclusive breastfeeding incidents towards stunting in Tapung, Kampar Regency, with a P value of 0,000 . 


\section{REFERENCES}

[1]. Afriyanti, L. 2015. The Relationship between Mother's Knowledge of Nutrition and Parenting with the Occurrence of Stunting in Children Aged 6-24 Months in the Working Area of the Nanggalo Health Center in Padang City 2015. Andalas University. Essay

[2]. Amaliah, N., K. Sari., And B.Ch. Rosha. 2012. Short Body Height Status Risks to Menarche Age Delay in Adolescent Girls Age 10-15 Years. 2012 Nutrition Panel, 35 (2): 150-158.

[3]. Anwar, F., A. Khomsan., A.V.R. Mauludyani., And K.R. Ekawidyani. 2014. Stunting Problems and Solutions Due to Malnutrition in Rural Areas. IPB Press. Bogor city.

[4]. Ministry of PDTT. 2017. The Village Pocket Book in Handling Stunting. Jakarta: Ministry of Villages, Disadvantaged Regions and Transmigration.

[5]. Mamonto T, 2015. Factors related to exclusive breastfeeding for infants in the work area of the City Health Center of Bangon, Journal of Public Health. 1: 56-66.

[6]. Millenium Challenga Account Indonesia. 2014. Stunting and the Future of Indonesia. Obtained from www.mca-indonesia.go.id

[7]. Mufida L., Tri DW, Jaya M.2015. The basic principle of complementary breastfeeding food (MPASI) for babies 6-24 months. Journal of food and agroindustry. 3 (4): $1646-51$

[8]. Noci, R.E. 2016. The Relationship of Mother's Parenting to Stunting in New Children Entering Elementary School in Nanggalo District, Padang City. Andalas University. Essay.

[9]. Proboningrum, A.R., and A. Khomsan. 2016. Parenting, Psychosocial Stimulation, and Toddler Nutrition Status in Kudus Regency. Nutrition Journal, Vol. 18 (1): 7-10.

[10]. Oktarina, Z., and T. Sudiarti. 2013. Stunting Risk Factors in Toddlers (24-59 Months) in Sumatra. Journal of Nutrition and Food, November 2013, 8 (3): 175-180. 